\title{
ANALISA PROFIL KADAR C-REACTIVE PROTEIN PADA STATUS KESEHATAN PERIODONTAL PASIEN DIABETES MELITUS TIPE 2 (Studi di Rumah Sakit Islam Sultan Agung Semarang)
}

\author{
Nirmala Yekti*, Yayun Siti Rochmah*, Rochman Mujayanto*
}

\begin{tabular}{|c|}
\hline Keywords: \\
Diabetes Mellitus, \\
Periodontitis, \\
C-Reactive Protein, \\
Oral hygiene \\
\hline
\end{tabular}

\section{ABSTRACT}

Background: Periodontitis is the inflammation of periodontal tissue that is characterized by the migration to the apical epithelial jungsional with clinical signs of an increase in probing depth. Periodontitis is one of the oral manifestations in patients with DM. CRP is a protein alphaglobulin produced in the liver and increased levels of inflammatory process in the event. In diabetic patients increased levels of CRP resulted in periodontal tissue destruction. The purpose of this study was to determine the profile of CRP levels in patients with type 2 diabetes mellitus with periodontitis. Method: This research was conducted using analytical observational research methods. The samples used were type 2 diabetes patients with periodontitis and the control group of patients with type 2 diabetes without periodontitis in Sultan Agung Islamic Hospital . All of samples were examined periodontal index, levels of CRP and oral hygiene. Result: Mann Whitney's test show significance $p=0.000$, which means there are significant differences between groups. Spearman-Kendall's correlation show that relationship between CRP and periodontal index $p=0.000$ with a correlation coefficient 0.875 means $p<0.05$ there was that a significant relationship exists between them and the relationship is strong. In relation $\mathrm{OH}$ and periodontitis index $p=0.030$ with a correlation coefficient of 0.650 means $p<0.05$ there was that a significant relationship exists between them and the relationship strong. Conclusion: It can be concluded that CRP levels in patients type 2 diabetes with periodontitis is higher than the patients type 2 diabetes without periodontitis. And there is a strong relationship between levels of CRP with periodontitis index, and also a strong relationship between periodontitis and $\mathrm{OH}$ index .

\section{PENDAHULUAN}

Diabetes mellitus (DM) merupakan penyakit yang sering kita jumpai di masyarakat. DM merupakan suatu kelompok penyakit metabolik karakteristik yang ditandai dengan peningkatan kadar gula darah, yang terjadi karena gangguan sekresi insulin, kerja insulin, maupun kedua-duanya ${ }^{1}$. Ketidaksesuaian kerja insulin pada penyakit DM ini, mengakibatkan glukosa dari pembuluh darah tidak mampu masuk ke jaringan. Keadaan ini menyebabkan sebagian besar glukosa tetap berada dalam sirkulasi darah sehingga terjadi hiperglikemi². Hiperglikemia kronik pada diabetes berhubungan dengan kerusakan jaringan jangka panjang, disfungsi atau kegagalan beberapa organ tubuh, terutama mata, ginjal, saraf, jantung, dan pembuluh darah $^{3}$.

DM bukan merupakan penyakit menular dan prevalensinya semakin meningkat dari tahun ke tahun. Laporan dari WHO mengenai studi populasi DM di berbagai negara, jumlah penderita DM

\footnotetext{
*Program Pendidikan Dokter Gigi Fakultas Kedokteran Gigi Unissula Semarang, ** Departemen Bedah Mulut dan Maksilofasial Fakultas Kedokteran Gigi Unissula Semarang, ${ }^{* * *}$ Departemen Oral Medicine Fakultas Kedokteran Gigi Unissula Semarang

Korespondesi: nirmalayektidrg@gmail.com
} 
pada tahun 2000 di Indonesia menempati urutan ke-4 terbesar dalam jumlah penderita DM dengan prevalensi 8,4 juta jiwa. Urutan diatas adalah Amerika Serikat (17,7 juta jiwa), China (20,8 juta jiwa) dan India (31,7 juta jiwa $)^{4}$. Hasil dari data laporan puskesmas Kota Semarang pada tahun 2011 didapatkan jumlah kasus DM adalah sebanyak 59.877 kasus, terdiri atas 14.326 DM Tipe 1 dan 45.551 kasus DM Tipe $2^{5}$.

Salah satu komplikasi diabetes mellitus yang cukup serius di bidang kedokteran gigi adalah oral diabetic, diantaranya resorbsi tulang alveolar, kalkulus, gingivitis, periodontitis, xerostomia, burning mouth syndrome (BMS), kandidiasis, penyembuhan luka yang lama dan abnormal, peningkatan infeksi, penurunan aliran saliva, pembesaran glandula saliva, dan lain-lain ${ }^{6}$. Dari sekian banyak komplikasi, periodontitis merupakan komplikasi yang paling sering terjadi pada penderita DM. Periodontitis adalah inflamasi jaringan periodontal yang ditandai dengan migrasi epitel jungsional ke apikal dengan tanda klinis peningkatan kedalaman probing, kehilangan perlekatan, dan biasanya tidak ada rasa sakit ${ }^{7}$. Pada pasien DM, kadar sitokin yang lebih tinggi akan memperparah kerusakan jaringan periodontal ${ }^{8}$.

Penderita DM memiliki sistem imun yang rendah sehingga mudah terkena infeksi. Dengan demikian, diketahui bahwa periodontitis dan diabetes mempunyai hubungan timbal balik dan saling berhubungan ${ }^{9}$.

C-Reactive Protein merupakan suatu alfa-globulin yang diproduksi di hepar dan kadarnya akan meningkat tinggi pada proses keradangan serta kerusakan jaringan ${ }^{10}$. Pada periodontitis, bakteri atau produknya (seperti LPS) menginvasi jaringan secara indirect, merangsang makrofag dan monosit untuk menghasilkan mediator inflamasi seperti sitokin, khusunya IL-6 dan IL-1. Karena adanya peningkaan mediator inflamasi ini akan merangsang produksi dan mengaktivasi enzim yang merusak jaringan ikat, mematikan fibroblas, meningkatkan produksi osteoklas, dan mematikan sel osteoblas ${ }^{11}$.

Peningkatan kadar CRP sering dihubungkan dengan kejadian DM dan penyakit kardiovaskular ${ }^{12}$. Penelitian membuktikan kadar CRP serum pada penderita DM sebanyak $2,40 \mathrm{mg} / \mathrm{L}$ dan $1,67 \mathrm{mg} / \mathrm{L}$ pada yang bukan penderita diabetik $^{13}$.

Berdasarkan hal-hal yang telah dijabarkan diatas, maka penulis ingin meneliti lebih lanjut mengenai hubungan kadar CRP pada pasien DM dengan periodontitis atau tanpa periodontitis di Rumah Sakit Islam Sultan Agung Semarang.

\section{METODE PENELITIAN}

Jenis penelitian yang dilakukan adalah penelitian observasional analitik dengan menggunakan rancangan cross sectional. Penelitian ini dilakukan di Rumah Sakit Islam Sultan Agung Semarang sejak tanggal 1 Desember - 20 Desember 2013. Sampel penelitian yaitu pasien DM tipe 2 dengan periodontitis berjumlah 11 orang dan kontrol yaitu pasien DM tipe 2 tanpa periodontitis berjumlah 11 orang. Penetapan sampel menggunakan selective random sampling yaitu sampel diambil berdasarkan kriteria inklusi dan eksklusi. Adapun kriteria inklusi adalah sebagai berikut: penderita DM tipe 2 terdiagnosa, termasuk DM tipe 2 terkontrol \pm 3 bulan, belum pernah melakukan perawatan periodontal selama \pm 1 tahun, tidak memiliki penyakit sistemik (hipertensi, ginjal, jantung, AIDS), dan bersedia menandatangani informed consent. Adapun kriteria ekslusinya adalah wanita hamil.

Dari kuesioner ditetapkan kelompok sampel dan kelompok kontrol. Kemudian kelompok sampel dan kelompok kontrol diperiksa kedalaman poket periodontalnya menggunakan probe WHO dan 
dimasukkan pada Indeks Periodontal. Gigi yang diperiksa adalah 6 gigi terpilih yang dianggap mewakili keseluruhan rongga mulut (Ramfjord teeth). Keenam gigi tersebut adalah 16, 21, 24, 36, 41, 44.

Bila salah satu gigi ini hilang maka digantikan oleh gigi di sampingnya $(17,11,25,37$, $42,45)$. Dengan skor kriteria 0 bila tidak ada peradangan dan pembentukan poket, skor 4 bila terdapat poket kurang dari 3 $\mathrm{mm}$, skor 5 bila terdapat poket 3-6 $\mathrm{mm}$, dan skor 6 bila terdapat poket lebih dari $6 \mathrm{~mm}$.

Kemudian dilakukan pemeriksaan Oral hygiene. Indeks yang digunakan adalah $\mathrm{OHI}-\mathrm{S}$ yang diperoleh dari penjumlahan Cl-S dan DI-S pada permukaan gigi yang sudah ditentukan yaitu bagian buccal gigi 16 dan 26, bagian labial gigi 11 dan 31, bagian lingual gigi 36 dan 46 .

Selanjutnya dilakukan pemeriksaan kuantitatif CRP di Balai Laboratorium Kesehatan dengan metode aglutinasi lateks direct. Sebelum dilakukan pemeriksaan kautitatif, dilakukan pemeriksaan kualitatif terlebih dahulu.

Dari hasil penelitian selanjutnya dilakukan uji normalitas dengan Shapiro Wilk dan uji homogenitas menggunakan Levene'stest. Kemudian untukmengetahui nilai signifikansi kadar CRP pada pasien DM tipe 2 dengan periodontitis dan tanpa periodontitis dilakukan uji Mann Whitney. Selanjutnya, untuk mengetahui hubungan nilai CRP dan $\mathrm{OH}$ terhadap indeks periodontitis dilakukan uji Spearman-Kendal.

\section{HASIL PENELITIAN}

Dari uji normalitas menggunakan Shapiro-Wilk didapatkan data tidak terdistribusi normal (tabel 1), dan dari uji homogenitas menggunakan Levene's test didapatkan data tidak terdistribusi homogen (tabel 2)

Tabel 2. Uji homogenitas data nilai CRP kelompok sampel dan kelompok kontrol

Levene's Test for Equality variances

$\frac{5.091}{\text { Keterangan: signifikansi } \mathrm{p}>0.05}$

Sig. 0,001

Ditemukan perbedaan jumlah CRP antara kelompok sampel dan kelompok kontrol. Diketahui bahwa nilai CRP kelompok sampel sebesar $33.82 \pm 32.563$ namun disertai nilai standart deviasi yang tinggi yaitu \pm 32.563 , hal ini dikarenakan pada kelompok sampel memiliki rentang nilai CRP yang cukup jauh yaitu nilai tertinggi adalah 96 dan terendah adalah 12. Sedangkan pada kelompok kontrol didapatkan nilai 7.64 dengan standar deviasi \pm 2.803 (tabel 3 )

Tabel 3. Rerata \pm standar deviasi jumlah CRP antara kelompok sampel dan kelompok kontrol pada pasien dengan penyakit DM tipe 2

\begin{tabular}{ll}
\hline Kelompok Perlakuan & $\mathrm{x} \pm \mathrm{SB}$ \\
\hline Kelompok kontrol & $7.64 \pm 2.803$ \\
\hline Kelompok sampel & $33.82 \pm 32.563$ \\
\hline $\mathrm{x}:$ rerata diameter & \\
$\mathrm{SB}:$ simpangan baku &
\end{tabular}

Hasil analisa data dengan Uji Mann Whitney pada kadar CRP pasien DM 
tipe 2 dengan periodontitis dan tanpa periodontitis menunjukkan nilai $p$ (Sig) $=0.000$ yang berarti nilai $p<0.005$, sehingga dari hasil tersebut dapat disimpulkan bahwa terdapat perbedaan yang signifikan antara kadar CRP pasien DM tipe 2 dengan periodontitis dan tanpa periodontitis (Tabel 4).

Tabel 4. Rangkuman uji Mann Whitney

\begin{tabular}{ll}
\hline Kelompok & $\mathrm{P}$ \\
\hline Sampel dan Kontrol & $0,000^{*}$ \\
\hline
\end{tabular}

Keterangan : signifikansi $\mathrm{p}<0.05$

Tabel 5. Hubungan nilai CRP dan $\mathrm{OH}$ terhadap indeks periodontitis
Berdasarkan uji korelasi SpearmanKendall pada hubungan nilai CRP terhadap indeks periodontitis didapatkan $p($ Sig $)=0.000$ dengan koefisien korelasi 0.875 berarti $p<0.05$ dapat disimpulkan terdapat hubungan yang signifikan antara keduanya dan hubungannya kuat. Pada hubungan $\mathrm{OH}$ dengan indeks periodontitis didapatkan $\mathrm{p}(\mathrm{Sig})=0.30$ dengan koefisien korelasi 0.650 berarti $p$ $<0.05$ dapat disimpulkan terdapat hubungan yang signifikan antara keduannya dan hubungannya kuat (Tabel 5).

\begin{tabular}{|c|c|c|c|c|c|}
\hline & & & CRP & $\begin{array}{l}\text { Indeks } \\
\text { Periodontitis }\end{array}$ & $\mathrm{OH}$ \\
\hline \multirow{3}{*}{\multicolumn{2}{|c|}{ Kendall's tau_b CRP }} & $\begin{array}{l}\text { Correlation } \\
\text { Coefficient }\end{array}$ & 1.000 & $.792^{* *}$ & .561 \\
\hline & & Sig. (2-tailed) & . & .003 & .057 \\
\hline & & $\mathrm{N}$ & 11 & 11 & 11 \\
\hline & \multirow[t]{3}{*}{$\begin{array}{l}\text { Indeks } \\
\text { Periodontitis }\end{array}$} & $\begin{array}{l}\text { Correlation } \\
\text { Coefficient }\end{array}$ & .792 & 1.000 & .592 \\
\hline & & Sig (2-tailed) & .003 & & .040 \\
\hline & & $\mathrm{N}$ & 11 & 11 & 11 \\
\hline & \multirow[t]{3}{*}{$\mathrm{OH}$} & $\begin{array}{l}\text { Correlation } \\
\text { Coefficient }\end{array}$ & .561 & $.592^{* *}$ & 1.000 \\
\hline & & Sig (2-tailed) & .057 & .040 & . \\
\hline & & $\mathrm{N}$ & 11 & 11 & 11 \\
\hline \multirow[t]{9}{*}{ Spearman's tho } & CRP & $\begin{array}{l}\text { Correlation } \\
\text { Coefficient }\end{array}$ & 1.000 & $.875^{\circ *}$ & .603 \\
\hline & & Sig. (2-tailed) & . & .000 & .050 \\
\hline & & $\mathrm{N}$ & 11 & 11 & 11 \\
\hline & \multirow[t]{3}{*}{$\begin{array}{l}\text { Indeks } \\
\text { Periodontitis }\end{array}$} & $\begin{array}{l}\text { Correlation } \\
\text { Coefficient }\end{array}$ & .875 & 1.000 & .650 \\
\hline & & Sig. (2-tailed) & .000 & . & .030 \\
\hline & & $\mathrm{N}$ & 11 & 11 & 11 \\
\hline & \multirow[t]{3}{*}{$\mathrm{OH}$} & $\begin{array}{l}\text { Correlation } \\
\text { Coefficient }\end{array}$ & .603 & $.650^{* *}$ & 1.000 \\
\hline & & Sig. (2-tailed) & .050 & .030 & . \\
\hline & & $\mathrm{N}$ & 11 & 11 & 11 \\
\hline
\end{tabular}




\section{DISKUSI}

Ditunjukkan pula pada Uji Mann Whitney bahwa terdapat perbedaan yang signifikan terhadap kedua kelompok perlakuan sampel dan kelompok perlakuan kontrol tersebut. Jumlah kadar CRP pada orang sehat biasanya $\leq 5 \mathrm{mg} / \mathrm{l}^{14}$. Pada pasien DM tipe 2, terjadi peningkatan kadar glukosa darah, yang berakibat terjadinya kondisi hiperglikemia secara kronis sehingga akan meningkatkan kadar ROS dalam tubuh. ROS adalah radikal bebas yang terbentuk ketika $\mathrm{O}_{2}$ menerima elektron bebas. Jumlah ROS yang berlebihan didalam sel akan mengaktifkan protein kinase-C (PKC) pathway. PKC pathway akan mengaktivasi $N F-K \beta$ yang merupakan faktor transkripsi untuk mengaktifkan gen-gen proinflamasi dalam pembuluh darah, sehingga aktivasi dari $N F-K \beta$ akan membuat jumlah sitokin proinflamasi meningkat ${ }^{15}$. Dengan meningkatnya jumlah sitokin pro inflamasi dalam darah, maka hepar akan merespon dengan mensintesis $\mathrm{CRP}^{16}$. Hal ini memperkuat bahwa pada pasien DM tipe 2 terjadi peningkatan kadar CRP.

Dari uji korelasi Spearman-Kendall pada hubungan CRP dan Indeks periodontitis didapat sign $=0,000$ dengan koefisien korelasi 0,875 berarti $p<0,05$ dapat disimpulkan terdapat hubungan yang signifikan antara keduanya dan hubungannya kuat. Peningkatan kadar CRP mempunyai hubungan yang erat dengan peningkatan derajat periodontitis. Pada pasien DM tipe 2, terjadi peningkatan kadar glukosa darah, yang berakibat terjadinya kondisi hiperglikemia secara kronis. Kondisi hiperglikemia yang kronis ini dapat meningkatkan kadar ROS dalam tubuh yang dapat merusak membran pada sel dengan menginduksi proses lipid peroxidation yang akibatnya dapat merusak sel lebih lanjut ${ }^{17}$. Berdasarkan penelitian Seymour dkk juga menyatakan bahwa adanya hubungan antara periodontitis kronis dengan peningkatan kadar $C R P^{18}$. Selain itu pada penelitian
Amar,dkk (2003) dan Tonetti,dkk (2007) yang sudah dilakukan terhadap 400 penderita PJK (Penyakit Jantung Koroner), kadar tertinggi CRP terlihat pada kebanyakan penyakit periodontal lanjut. Sehingga apabila dihubungkan dengan penelitian ini, kemungkinan ada hubungan antara kadar CRP pada pasien DM tipe 2 dengan penyakit periodontal lanjut terhadap resiko terjadinya PJK. Ada beberapa faktor yang dapat meningkatkan kadar CRP yang tidak diikutsertakan pada penelitian ini yaitu infeksi, peradangan, trauma, dan luka bakar. Selain PJK dan DM, ada penyakit-penyakit lain dengan kadar CRP tinggi yaitu Active juvenille arthritis, Sindroma vaskulitis, Arthritis reumatoid, Demam reumatik, Infark miokard, Penyakit Crohn (kelitis granulomatosa), Amiloidosis sekunder, dan infeksi-infeksi bakteri ${ }^{19}$.

Pada hubungan $\mathrm{OH}$ dan Indeks periodontitis didapat sign $=0,030$, dengan koefisien korelasi 0,650 berarti $p<0,05$ dapat disimpulkan terdapat hubungan yang signifikan antara keduanya dan hubungannya kuat. Pada pasien penderita DM tipe 2 dengan oral hygiene yang buruk, lebih rentan terhadap gingivitis, hyperplasia gingiva, dan periodontitis ${ }^{20}$. Penyakit periodontal dimulai dengan adanya plak bakteri yang terakumulasi dipermukaan gigi. Bakteri dan produknya (seperti LPS) akan merangsang sel (seperti makrofag dan monosit) untuk menghasilkan mediator inflamasi (seperti sitokin yang meliputi $I L-6, I L-\beta$ dan $T N F-\alpha$ ). Sitokin IL-6, IL- $\beta$ dan TNF $\alpha$ bertugas mensitesa $C R P$. Sehingga jumlah $C R P$ pada periodontitis akan meningkat. $C R P$ dikenal sebagai penanda fase akut inflamasi dan ada hubungan antara peningkatan kadar plasmanya dengan kerusakan jaringan. Hal ini memperkuat bahwa pada pasien DM tipe 2 dengan $\mathrm{OH}$ yang buruk akan mengakibatkan periodontitis sehingga kadar CRP semakin meningkat jika dibandingkan dengan pasien DM tanpa periodontitis. 


\section{KESIMPULAN}

Terdapat perbedaan kadar CRP pada pasien DM tipe 2 dengan periodontitis dan tanpa periodontitis serta terdapat hubungan yang kuat antara peningkatan kadar CRP terhadap indeks periodontal, dan status $\mathrm{OH}$ terhadap indeks periodontal pada pasien DM tipe 2 .

\section{DAFTAR PUSTAKA}

1. Anonim. 2003. Report of the Expert Committee on the Diagnosis and Classification of Diabetes Melitus. Diabetes Care, Vol. 26, No. 1, h. 5.

2. Carranza, F.A., Newman, M.G., Takei, H.H., Klokkevold, P.R. 2006. Carranza's Clinical Periodontology (10th ed). Philadelphia: WB Saunders.

3. Purnamasari, D. 2009. Diagnosis dan Klasifikasi Diabetes Melitus dalam Buku Ajar IImu Penyakit Dalam (5th ed), Jilid III, h. 1880. Jakarta: Interna Publishing.

4. Darmono., Suhartono, T., Pemayun, T., Padmomartono, F.S (ed). 2007. Naskah Lengkap : Diabetes Mellitus Ditinjau dari Berbagai Aspek Penyakit Dalam. Semarang : Balai Penerbit Universitas Diponegoro Anonim, 2011. Profil Kesehatan Kota Semarang Tahun 2011 . Diakses 1 Agustus 2013 dari www. dinkeskotasemarang.files.wordpress.com

5. Anonim, 2011. Profil Kesehatan Kota Semarang Tahun 2011 . Diakses 1 Agustus 2013 dari www.dinkeskotasemarang.files. wordpress.com

6. Mealey, B.L., Oates, T.W. 2006. Diabetes Mellitus and Periodontal Diseases. J Periodontol, Vol.77, No. 8, h.1289-1303.

7. Gray, J. 2005. Faktor Periodontal yang Berkaitan dengan Plak: Patogenesis dalam The Periodonti Syllabus (terj). Jakarta: EGC. h. 30.

8. Rose, L.F., Genco, R.C., Cohen, D.W., Mealey, B.L. 2004. Periodontics Medicine, Surgery, and Implants. Philadelphia: Elsevier Mosby.

9. Lamster, I.B., Lalla, E., Borgnakke, W.S., Taylor, G.W. 2008. Relationship Between Oral Health and Diabetes Mellitus. The Journal of American Dental Association, Vol. 139, h. 20.

10. Susanto, H.K., John M.F Adam. 2009. Plasminogen Activator Inhibitor-1 and High Sensitivity C-Reactive Protein in Obesity. The Indonesian Journal of Medical Science, Vol. 2, no.1, h. 23-31.

11. Eley, B.M., Soory, M., Manson, J.D. 2010. Periodontics (6th ed). Philadelphia: Elsevier.

12. Clare-Salzler, M.J., Crawford, J.M., Kumar, V. 2007. Pankreas dalam Buku Ajar Patologi (7th ed), Jilid III, h. 711. Jakarta: EGC.
13. Festa, A., D’Agostino, R., Howard, G.Jr., Mykkänen, L., Tracy, R.P., Haffner, S.M. 2000. Chronic Subclinical Inflammation as Part of the Insulin Resistance Syndrome: The Insulin Resistance Atherosclerosis Study (IRAS). The Journal of American Dental Association, Vol. 102 , h. 42-47.

14. Ramamoorthy, dkk. 2012. A review of C-reactive protein: A diagnostic indicator in periodontal medicine. J Pharm Bioallied Sci, vol. .4, suppl 2, h. S422-S426

15. Brownlee, M. 2005. Banting Lecture 2004: The Pathobiology of Diabetic Complication . A unifying Mechanism. Diabetes, Vol. 54, h. 1615-1625.

16. Reeves, G. 2007. Abnormal Laboratory Result: C-Reactive Protein. Australian Prescriber, Vol. 30, no. 3, h. 74-76.

17. Lieberman, M., Marks, A.D. 2009. Mark's Basic Medical Biochemistry: A Clinical Approach (3th ed). Baltimore: Lippincott Williams and Wilkins.

18. Seymour, G.J., Ford, P.J., Cullinan, M.P., Leishman, S., Yamazaki, K. 2007. Relationship between Periodontal Infections and Systemic Disease. Clinical Microbiology and Infectious Diseases. vol. 13, suppl. 4, h. 3-10

19. Carl, E.S., Jack, W.S. 1996. Pemilihan Uji Laboratorium Yang efektif. Jakarta: EGC.

20. Rees, T. 2005. Faktor Penyerta Sistemik dalam The Periodonti Syllabus (terj). h.21. Jakarta: EGC. 